\title{
What makes employees resilient to job demands? : The role of core self-evaluations in the relationship between job demands and strain reactions
}

Citation for published version (APA):

van Doorn, R. R. A., \& Hülsheger, U. R. (2015). What makes employees resilient to job demands? : The role of core self-evaluations in the relationship between job demands and strain reactions. European Journal of Work and Organizational Psychology, 24(1), 76-87. https://doi.org/10.1080/1359432X.2013.858700

Document status and date:

Published: 01/01/2015

DOI:

10.1080/1359432X.2013.858700

Document Version:

Publisher's PDF, also known as Version of record

\section{Document license:}

Taverne

Please check the document version of this publication:

- A submitted manuscript is the version of the article upon submission and before peer-review. There can be important differences between the submitted version and the official published version of record.

People interested in the research are advised to contact the author for the final version of the publication, or visit the DOI to the publisher's website.

- The final author version and the galley proof are versions of the publication after peer review.

- The final published version features the final layout of the paper including the volume, issue and page numbers.

Link to publication

\footnotetext{
General rights rights.

- You may freely distribute the URL identifying the publication in the public portal. please follow below link for the End User Agreement:

www.umlib.nl/taverne-license

Take down policy

If you believe that this document breaches copyright please contact us at:

repository@maastrichtuniversity.nl

providing details and we will investigate your claim.
}

Copyright and moral rights for the publications made accessible in the public portal are retained by the authors and/or other copyright owners and it is a condition of accessing publications that users recognise and abide by the legal requirements associated with these

- Users may download and print one copy of any publication from the public portal for the purpose of private study or research.

- You may not further distribute the material or use it for any profit-making activity or commercial gain

If the publication is distributed under the terms of Article $25 \mathrm{fa}$ of the Dutch Copyright Act, indicated by the "Taverne" license above, 


\section{What makes employees resilient to job demands? The role of core self-evaluations in the relationship between job demands and strain reactions}

\section{Robert R. A. van Doorn \& Ute R. Hülsheger}

To cite this article: Robert R. A. van Doorn \& Ute R. Hülsheger (2015) What makes employees resilient to job demands? The role of core self-evaluations in the relationship between job demands and strain reactions, European Journal of Work and Organizational Psychology, 24:1, 76-87, DOI: 10.1080/1359432X.2013.858700

To link to this article: https://doi.org/10.1080/1359432X.2013.858700

Published online: 25 Nov 2013.

Submit your article to this journal $\square$

Џ Article views: 1539

a

View related articles

View Crossmark data $־$

Citing articles: 18 View citing articles $\widetilde{ }$ 


\title{
What makes employees resilient to job demands? The role of core self-evaluations in the relationship between job demands and strain reactions
}

\author{
Robert R. A. van Doorn and Ute R. Hülsheger \\ Department of Work and Social Psychology, Maastricht University, Maastricht, The Netherlands
}

\begin{abstract}
Contemporary theory claims that job demands will not lead to negative strain reactions when job related resources are in place as a buffer. In the present article this idea is extended by focusing on person-related resources that are not inherently related to the job, namely core self-evaluations (CSE). This general trait represents an individual's evaluation of self-worth and functioning, and is composed of four accepted personality traits, namely self-esteem, locus of control, general self-efficacy, and emotional stability. The present article tested the idea that CSE functions as a person-related resource and acts as a buffer between job demands and strain reactions. In two studies with samples from separate organizations it was shown that CSE moderated the relationship of job demands (emotional job demands, work load, and shift work) with psychological distress. Results indicate that CSE functions as a personal resource and acts as a buffer between job demands and strain reactions. It is discussed how these results add to contemporary stress models.
\end{abstract}

Keywords: Job demands; Psychological distress; Core self-evaluations; Person-related resources; Depression; Irritation.

Achieving organizational goals often presupposes that employees maximize their efforts to perform their job. A potential side effect is that subsequent increased work demands may instigate mental and physical fatigue or even exhaustion. Prolonged exposure to these circumstances have been shown to lead to negative work attitudes and long lasting psychological or medical symptoms, such as burnout (Bakker, Demerouti, \& Verbeke, 2004; Demerouti, Bakker, Nachreiner, \& Schaufeli, 2001). Contemporary notions about the factors related to possible work-related strain reactions include job demands as potential stressors, but also the available job-related resources that may act as a buffer that precludes stressors from causing negative strain reactions.

The present article adds to these notions on the interplay between job-related demands and strain by focusing on core self-evaluations as a potential resource within the individual that may positively moderate how job demands relate to negative strain reactions. In doing so, we build upon the job demand resources model (Demerouti et al., 2001) and on previous research on the role of personal resources in the job demands-strain relationship (Cohen \& Edwards, 1989; Ganster \& Fusilier, 1989; Ganster \& Schaubroeck, 1991; Jex \&
Bliese, 1999; Jex \& Elacqua, 1999; May, Schwoerer, Reed, \& Potter, 1997; Parkes, 1990; 1991; Pierce, Gardner, Dunham, \& Cummings, 1993). Two independent studies are presented in which it is investigated how core self-evaluations function as a person-related resource and provide resilience to the effects of different job demands on how individuals experience strain. While Study 1 uses a typical self-report measure of job demands, results will be replicated in Study 2 with an objective measure of job demands (shift work). Hypotheses will be formulated on how the role of these personal resources may add to the literature on the interplay between job-related demands and resources in instigating negative strain reactions.

\section{DEMAND-STRAIN MODELS}

Most recent models, such as the Job Demand Resources model (JDR; Demerouti et al., 2001; Demerouti, Mostert, \& Bakker, 2010) and the Demand Induced Strain Compensation Model (DISC; de Jonge \& Dormann, 2006; de Jonge, Dormann, \& van Vegchel, 2004) strongly underline that both demands and resources are part of the work environment in all its complexity (Crawford, LePine, \& Rich, 2010; de Jonge \& Dormann, 2006;

Correspondence should be addressed to Robert R.A. van Doorn, Department of Work and Social Psychology, Maastricht University, PO Box 616, 6200 MD, Maastricht, The Netherlands. E-mail: r.vandoorn@maastrichtuniversity.nl 
Demerouti et al., 2001). Job demands typically refer to potential physical, social, and organizational job aspects. These job aspects require prolonged physical and/or mental effort, at potential physiological and psychological costs. Examples of job demands include workload (Bakker, van Veldhoven, \& Xanthopoulou, 2010), emotional demands and work-home conflict (Bakker et al., 2004; Demerouti, Geurts, Bakker, \& Euwema, 2004).

According to the JDR and DISC models, job resources refer to physical, psychological, social, and organizational aspects of the job. To make them job resources, they should either be functional in achieving work goals, or should play a role in reducing job demands, or discernibly take part in lessening the associated physiological and psychological costs (Bakker, Demerouti, \& Euwema, 2005). According to the DISC model, emotional, cognitive or physical job resources need to closely match the demands they provide a buffer against (de Jonge \& Dormann, 2006; de Jonge, Spoor, Sonnentag, Dormann, \& van den Tooren, 2012) in order to deploy their compensatory function. These intricate relationships between demands and resources are believed to operate in a wide variety of organizations and not only in human services occupations (Demerouti et al., 2001). These notions have been successful in explaining the origins of both short term stress-reactions (Demerouti, Bakker, Nachreiner, \& Ebbinghaus, 2002) and longer-lasting burnout symptoms, independent of occupation context (Demerouti et al., 2001). Especially the JDR model has attracted a lot of research in recent years (for a meta-analysis see Crawford et al., 2010), and both models have been substantial in advancing the literature on job strain. In both models, demands and resources are conceptualized as being inherently related to the immediate job environment (de Jonge \& Dormann, 2006; Demerouti et al., 2001). However, it is currently argued that personal characteristics of employees may also function as resources and help reduce potential negative effects of job demands.

\section{JOB-RELATED PERSONAL RESOURCES VERSUS PERSON-RELATED RESOURCES}

As both models were designed to describe job related demand-resource interactions, they do not specifically account for the classic distinction between organizational and social resources on the one hand, and personal resources on the other (Bakker \& Demerouti, 2007; Bakker, Hakanen, Demerouti, \& Xanthopoulou, 2007; Gabriel, Diefendorff, \& Erickson, 2011; Judge \& Hurst, 2007). Most recently an attempt has been made to extend the JDR model to account for job-related personal resources. They included organization-based selfefficacy, but also optimism and organizational based self-esteem. These resources were indeed found to act as successful buffers between job demands and strain reactions (Xanthopoulou, Bakker, Demerouti, \& Schaufeli, 2007). It is important to note that these personal characteristics were viewed as domain specific (Chang, Ferris, Johnson, Rosen, \& Tan, 2012) and closely related to the work context in which employees operate (Hobfoll, 1989, 2011; Xanthopoulou, Bakker, Demerouti \& Schaufeli, 2012). They typically include job-related cognitive features and action patterns that may develop over time, and may have a narrower scope (Chang et al., 2012) than job-independent and long-lasting personality structures believed to function as person-related resources. The latter are the focus of the present article (Hobfoll, 2002, 2011; Xanthopoulou et al., 2007; Xanthopoulou, Bakker, Demerouti, \& Schaufeli, 2009).

The view is currently taken that in many professions, work demands persist in eliciting strain-reactions even when all possible job-related resources have been brought in place (Folkman, 1984; Frankenhaeuser \& Johansson, 1986; Hobfoll, 2011; Van Veldhoven, De Jonge, Broersen, Kompier, \& Meijman, 2002). This leaves employees to their person-related resilience so as to cope with the negative effects of these demands. The Conservation of Resources Theory (COR; Hobfoll, 1989) describes a framework of how person-related resources are utilized in general settings but may also apply to job settings. The theory suggests that successful person-related resources may help an individual in the effective management of physical and mental effort to meet job demands, and bolster against their possible negative outcomes. In other words, the potential benefit is that employees with high levels of person-related resources may experience greater mastery or control that helps them to deal more effectively with demanding conditions, and in turn shield them from negative outcomes, such as exhaustion (Hobfoll, 2002; Xanthopoulou et al., 2007). In addition, person-related resources may form the basis for a development of a management capability of selecting, altering, and implementing job-related resources to meet stressful demands (Hobfoll, 2002). It is long known that effective resource management and control differ between individuals (Heckhausen \& Schulz, 1995; Hockey, 1997; Kahneman, 1973; Kanfer \& Ackerman, 1989), and these capabilities may be related to personality traits.

\section{PERSONALITY TRAITS AS PERSON-RELATED RESOURCES}

The idea of trait-like person-related resources as protection against strain reactions or even illness is not new (Cohen \& Edwards, 1989). Indeed, a number of wellestablished personality traits, namely self-esteem, selfefficacy, locus of control, and emotional stability, have been investigated in relation to potential vulnerability to stressors and demands (Cohen \& Edwards, 1989; 
Ganster \& Fusilier, 1989; Ganster \& Schaubroeck, 1991; Jex \& Bliese, 1999; Jex \& Elacqua, 1999; Kobasa \& Puccetti, 1983; May et al., 1997; Parkes, 1990, 1991; Pierce et al., 1993; Semmer, Jacobshagen, Meier, \& Elfering, 2007). Below, a concise overview is provided of how each personality trait has been investigated as a person-related buffer against life and work-related demands. It is subsequently argued and tested whether these four personality traits together, as represented by the recently introduced construct of core self-evaluations (Judge, Erez, Bono, \& Thoresen, 2003; Judge \& Hurst, 2007), may form an effective person-related shield against potential job demands.

Self-esteem has been suggested as an individual resource, as stress and demands may be seen as a threat to the self and self-worth, represented by self-esteem (Semmer et al., 2007). Self-esteem has been studied in psychiatric contexts as a potential ward against severe negative strain in war situations (Hobfoll, 2002). Also, individuals low in self-esteem in non-clinical contexts, have been suggested to be physiologically more susceptible to risks imposed by organizational events (Ganster \& Schaubroeck, 1991; Pierce et al., 1993). These ideas found corroboration in the finding that self-esteem acted as a moderator on the relationship between roleambiguity and depression and self-reported physical problems (Jex \& Elacqua, 1999).

Self-efficacy is a second well-established trait that has been related to individual vulnerability to demands, and may be considered as a potential personal resource. It reflects an individual's capability belief to produce desired levels of performance, but also to exercise influence over events that affect their lives (Bandura, 1994). This may suggest that individuals low in self-efficacy may be more susceptible to demanding events. Indeed, employees with low self-efficacy were influenced more by their physical job conditions than those with high self-efficacy (May et al., 1997). In addition, self-efficacy has been found to moderate the relation of stressors, such as work overload or role clarity, with strain reactions including self-reported psychological and physical symptoms (Jex \& Bliese, 1999; Jex, Bliese, Buzzell, \& Primeau, 2001).

In existentialistic settings, the construct hardiness is viewed as a basis to cope with negative life experiences (Cohen \& Edwards, 1989; Kobasa, 1979; Kobasa, Maddi, \& Zola, 1983; Kobasa \& Puccetti, 1983). Hardiness strongly relates to locus of control which represents an individual's belief in personal control in life (internality) rather than in control by outside forces or other individuals (externality). Internal control beliefs are viewed as important components of emotional adjustment and the ability to handle stress in general life and work (May et al., 1997; Parkes, 1991; Spector et al., 2002). Locus of control has been identified as a moderator of relations between life-stress and mental health outcomes (Spector et al., 2002). Moreover, locus of control has been shown to influence affective responses and mental health scores to demand and control in a work situation (Parkes, 1991).

Finally, neuroticism is a personality trait that may be influential as a personal resource in whether and how job demands may relate with strain reactions. The trait pertains to the tendency to have a negativistic cognitive/ explanatory style and to focus on negative often affective aspects of the self (Judge et al., 2003). Individuals high on negative affect (NA) displayed a higher reactivity, reported via the general health questionnaire to work demand than low NA individuals (Parkes, 1990). Moreover negative affectivity has been identified as moderator of the relation between perceptions of the work environment and stress reactions (Moyle, 1995). Recently, trait neuroticism has been suggested to affect the way in which mental resources are allocated under different demands (Smillie, Yeo, Furnham, \& Jackson, 2006; van Doorn \& Lang, 2010).

\section{CORE SELF-EVALUATIONS AS A PERSON-RELATED RESOURCE}

These studies illustrate that individuals inherently differ in their degree of reactivity to normative stressful events. Moreover, the four well-established traits may each constitute person-related resources that make employees less vulnerable to general and job demands commonly related to strain reactions or even illness (Van Veldhoven et al., 2002). We argue that the four traits may act in unison as a personality based shield against negative influences of job demands. Such a notion is in line with recent research in emphasizing the possible relationship of multiple personality traits to personalitybased vulnerability, but also to resilience to negative strain reactions (Schneider, Rench, Lyons, \& Riffle, 2012).

Judge and colleagues introduced a broad higher-order trait termed core self-evaluations (CSE) that comprises the four established traits self-esteem, general self-efficacy, locus of control and emotional stability (negative neuroticism). The construct reflects the basic, fundamental appraisal of one's worthiness, confidence, and capability as an individual (Chang et al., 2012). Notably, being a higher-order trait, CSE is more than the simple sum of the four core components. It captures the shared variance among the four traits, which have disproportionate loadings on the higher-order factor. It has consequently been argued that the effects of CSE may be different from the effects of its four traits (Chang et al., 2012). CSE is well-established in the IO literature and has been shown to be substantially related to job satisfaction, job performance, and well-being (Judge \& Bono, 2001; Judge, Erez, Bono, \& Thoresen, 2002; Judge \& Hurst, 2007; Judge, Locke, \& Durham, 1997; Judge, Locke, Durham, \& Kluger, 1998; Kammeyer- 
Mueller, Judge, \& Scott, 2009). For a review, see Chang et al. (2012).

Researchers have argued that CSE may not only directly and indirectly influence important work outcomes, but may also act as a moderator. That would be possible if reactions to work events and characteristics are influenced by employees' self-evaluations (Best, Stapleton, \& Downey, 2005; Chang et al., 2012; Luria \& Torjman, 2009). The present studies add to this line of research by investigating the moderating role of CSE in the job demands-strain relationship using not only selfreport measures of job demands (Study 1) but also an objective conceptualization of job demands in terms of shift work (Study 2).

Previous research suggests that job demands may be differentially related to strain depending on a person's standing on CSE. For instance, Kammeyer-Mueller and colleagues (Kammeyer-Mueller et al., 2009) investigated the role of CSE in the stress and coping process. A metaanalytic integration of empirical findings revealed that the four core traits of CSE were meaningfully related to employee's use of coping strategies: CSE was positively related to problem-solving coping and negatively to avoidance coping. Thus, by promoting adaptive coping mechanisms and influencing the way individuals deal with the exposure to stressors and job demands, CSE may weaken the job demands-strain relationship. Furthermore, building on work by Bolger and colleagues (Bolger \& Schilling, 1991; Bolger \& Zuckerman, 1995), Kammeyer-Mueller et al. (2009) argued that CSE may affect employees' reactivity to stressors (differential reactivity hypothesis). Due to a combination of a more favourable self-appraisal, confidence in their ability to cope with difficult situations, and a sense of personal agency, individuals with high CSE may experience fewer negative emotional and behavioural reactions to challenging work situations. Similarly, by providing individuals with a sense of self-worth and control, CSE may reduce the depletion of mental energy when employees face job demands (Chang et al., 2012; Kammeyer-Mueller et al., 2009).

To test the idea that CSE provides a shield against negative psychological effects of high job demands, two independent studies are conducted. The reason for performing two studies is to test the hypotheses on two separate samples drawn from different organizations. In addition, two separate studies make it possible to relate CSE to different operationalizations of strain reactions. And finally, the two studies will assess the potential function of CSE in weakening negative strain reactions on both self-reported job demands and an objective measure of job demands.

In Study 1, it is tested whether emotional job demands and workload interact with CSE in how they relate to psychological distress, as approached by the construct depression. Psycho-social demands distinguish work load from emotional job demands. Workload is assessed as the experienced pace and quantity of work. Emotional job demands concern perceived emotional tension in work situations and with other individuals (colleagues and clients), which is often related negatively with emotional well-being (Warr, 1990). Strain reactions are conceptualized with the construct depression, which has been recognized as a major job issue in the recent occupational health and work psychology literature (Gallagher, 2012; Kroenke \& Spitzer, 2002; Mark \& Smith, 2012). Depression comprises feelings of despair, low energy, decreased work interest, and decreased sense of usefulness (Dowrick, Kokanovic, Hegarty, Griffiths, \& Gunn, 2008). In Study 1, we test the idea that relationships of workload and emotional job demands with depression are moderated by CSE. The hypothesis is formulated as follows:

Hypothesis 1: The relationship of (a) workload and (b) emotional job demands with depression is moderated by CSE, such that relationships are stronger when CSE is low and weaker when CSE is high.

Study 2 involves a sample of hospital personnel that was collected with the focus on a well-known job demand, namely shift work, which deviates from regular work in terms of work hours that may vary across work days or even include night work (Costa, 2003). In comparison to self-reported workload and emotional job demands, shift work is not only a well-known stressor but also a variable that can be assessed objectively. It is therefore tested whether the relationship between shift work as a job demand and psychological distress is moderated by CSE.

Often reported effects of prolonged exposure to shift work include physiological problems often combined with psycho-social strains including work-home conflict (Kandolin, 1993). Shift work is regarded as a risk factor to physical and mental health (Costa, 2003; Frost \& Jamal, 1979; Härmä, Ilmarinen, Knauth, \& Rutenfranz, 1988). Despite research-based job improvements, such as decreasing demand by introducing less abrupt forward rotation of shifts, shift workers continue to experience strain, which may ultimately lead to depressive symptoms and burnout (Drake, Roehrs, Richardson, Walsh, \& Roth, 2004; Kandolin, 1993).

In Study 2, strain reactions are operationalized with the concept of irritation (Mohr, Müller, Rigotti, Aycan, \& Tschan, 2006; Mohr, Rigotti, \& Müller, 2005). Irritation has been identified as a mediator of the relationship between work stressors and depressive symptoms (Dormann \& Zapf, 2002). It is therefore regarded as a precursor of depression and may represent a warning for imminent psychological health threat (Mohr et al., 2005, 2006; Mohr \& Wolfram, 2010), and severe ill-effects of shift work such as depressive symptoms may become early apparent in heightened 
irritation (Mohr et al., 2006). It is investigated in the second study whether CSE buffers the relationship between shift work and irritation. The hypothesis is formulated as follows:

Hypothesis 2: CSE moderates the relationship between rotating shift work and irritation, such that the relationship is stronger when CSE is low and weaker when CSE is high.

\section{STUDY 1: CSE MODERATES THE RELATIONSHIP BETWEEN WORKLOAD, EMOTIONAL JOB DEMANDS, AND DEPRESSION}

\section{Method}

\section{Participants}

A total of 68 employees $(73 \%$ were female) from a large transportation organization in the Netherlands participated in this study, with a response rate of $59 \%$. Participants were working at several departments including finance administration, contract management and control, and their functions ranged from assistants to advisors, controllers, project coordinators and managers. Half of them had a higher education. They had an average age of $46.8(S D=8)$ years, worked 37 hours per week $(S D=5.2)$, and on average worked 21 years $(S D=11$ years $)$ at the company.

\section{Measures}

Core Self-Evaluations (CSE). CSE was measured with the Dutch translation (de Pater, Schinkel, \& Nijstad, 2007) of the 12-item scale developed by Judge and colleagues (Judge et al., 2003). Items were rated on 5-point Likert scales. Examples include "When I try, I generally succeed", and "I determine what will happen in my life". Half of the items are reversed scored, as they are stated as negative aspects of self-evaluations. The instrument has been shown to be quite reliable, as Cronbach- $\alpha$ 's ranged from .81 to .87 , and with an acceptable test-retest reliability of .81 (Judge et al., 2003). In the present study Cronbach's $\alpha$ was .83 .

Workload and Emotional Job Demands. Job demands were assessed with a shortened version of the Questionnaire on the Experience and Evaluation of Work (VBBA; Van Veldhoven et al., 2002). This questionnaire was constructed during 1992-1996 and the underlying constructs were based on the job content questionnaire (Karasek et al., 1998) and an instrument measuring job-related affective well-being (Warr, 1990). The instrument measures psycho-social job demands and distinguishes between emotional job demands, related to personal emotional involvement to situations and fellow workers, and workload (Bakker et al., 2010), pertaining to work pace and quantity of work. These psycho-social job demands can lead to a combination of workload and emotional strain reactions. Eleven items query potential workload including work pressure and work pace such as "Do you have to hurry to complete your day's work?", "Do you have problems with the work pace?" and "Do you have to work additionally hard to finish something?" Seven items measure emotional job demands in relation to work situations and other individuals, such as "Does your work confront you with emotional situations?" and "Is your work emotionally heavy?" The answering categories for all questions on psychosocial job characteristics ranged from "always (1)" to "never (4)". Cronbach $\alpha$ 's in the present study amounted to .80 for workload and .61 for emotional job demands. The potential consequences of this relatively low value will be discussed.

Depression. Depression was measured with the Patient Health Questionnaire (PHQ-9; Kroenke \& Spitzer, 2002), consisting of 9 items. The scale is based on the nine diagnosis criteria described in the DSM-IV (American Psychiatric Association, 2000). Items query the frequency of certain personal problems over the last two weeks, such as "Little interest of pleasure in doing things", "Feeling bad about yourself-or that you are a failure or have let yourself or your family down", and "Thoughts that you would be better off dead or of hurting yourself in some way". Answer categories ranged from "not at all" to "every day" on a five point scale. Cronbach's $\alpha$ amounted to .70.

Control variable. Gender functioned as a control variable as recent literature revealed gender differences regarding vulnerability to job demands and depressive symptoms (Herrero, Saldaña, Rodriguez, \& Ritzel, 2012; Smith \& Bielecky, 2012).

\section{Results}

Table 1 provides descriptive statistics and inter-correlations between study variables. Self-reported emotional job demands and workload displayed significant correlations with depression, while CSE was negatively related to depression. Two separate multiple regression analyses were conducted, regressing depression on workload and on emotional job demands, respectively. Independent variables were standardized prior to entering the analyses. In both analyses, CSE was entered as a potential moderator on the relationship between demands and psychological distress. Tests revealed that gender did not correlate to other variables, and did not alter the two final regression models.

Table 2 shows that both workload and emotional job demands were positively related to depression. CSE was negatively related to depression indicating that individuals scoring high on CSE generally experienced less distress than individuals scoring low on CSE. In 
TABLE 1

Reliabilities, means and standard deviations of, and bivariate correlations between variables of Study 1

\begin{tabular}{|c|c|c|c|c|c|c|}
\hline & Cronbach's $\alpha$ & Mean (SD) & 1 & 2 & 3 & 4 \\
\hline 1. Gender & - & - &. & & & \\
\hline 2. Depression & .70 & $1.19(0.22)$ & .19 & . & & \\
\hline 3. Workload & .80 & $1.36(0.38)$ & -.06 & $.25^{*}$ & & \\
\hline 4. Emotional job demands & .61 & $0.83(0.34)$ & .00 & $.45^{* * *}$ & $.58 * * *$ & . \\
\hline 5. CSE & .83 & $3.91(0.44)$ & .00 & $-.39 * *$ & -.18 & $-.25 *$ \\
\hline
\end{tabular}

$* * * p<.001, * * p<.01, * p<.05$.

TABLE 2

Depression as a function of CSE and workload and emotional job demands, with gender as control variable (Study 1)

\begin{tabular}{lcc}
\hline \multicolumn{3}{c}{ Dependent variable: Depression } \\
\hline Variable & $B$ & $S D$ \\
\hline Intercept & -0.154 & 0.128 \\
Gender & 0.429 & 0.243 \\
Workload & 0.517 & 0.289 \\
CSE & $-0.739^{* *}$ & 0.252 \\
Workload x CSE & $-1.793^{*}$ & 0.784 \\
$R^{2}$ & .29 & \\
Intercept & -0.177 & 0.119 \\
Gender & $0.462^{*}$ & 0.223 \\
Emotional job demands & $0.317^{* *}$ & 0.104 \\
CSE & $-0.305^{* *}$ & 0.102 \\
Emotional job demands x CSE & $-0.270^{* *}$ & 0.097 \\
$R^{2}$ & .41 & \\
\hline \multirow{2}{*}{$* *<.01, * p<.05}$. & &
\end{tabular}

addition, CSE moderated the relationship of both workload and emotional job demands with psychological distress. Interactions are visualized in Figures 1 and 2, showing that the relationship between job demands and depression is a function of employees' levels of CSE.

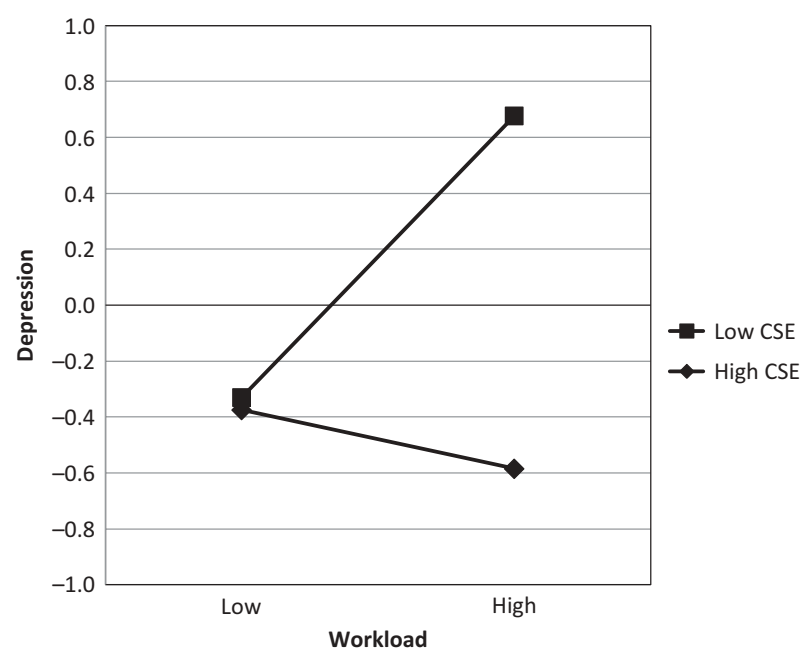

Figure 1. Study 1: Depression as a function of workload and core self-evaluations (CSE).

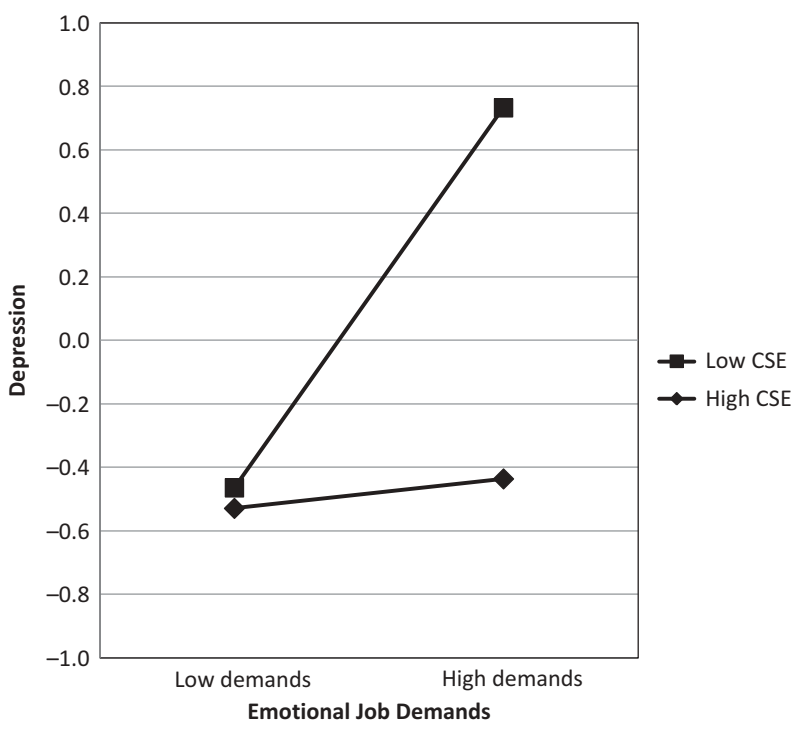

Figure 2. Study 1: Depression as a function of emotional job demands and core self-evaluations (CSE).

Supporting Hypothesis 1, the relationship was stronger and more positive for individuals with low core selfevaluations. Subsequent simple slope analyses revealed significant slopes for the regression of depression on low CSE for both workload $(\beta=0.29, \mathrm{t}(59)=2.95$, $p<.01)$, and for emotional job demands $(\beta=.13, \mathrm{t}(59)$ $=4.70, p<.0001)$. The slope of high CSE was not significant, neither for workload $(p>.5)$ nor for emotional job demands $(p>.7)$.

\section{Brief discussion of Study 1}

The results of the first study confirmed Hypothesis 1, stating that CSE moderates the relationship between workload and emotional job demands, and depression. A simple slope analysis further confirmed the buffer hypothesis stating that CSE diminishes the relationship between both workload and job demands, and depression. The analyses indeed showed that there was a significant positive relationship between both workload and emotional job demands, and depression when CSE was low, and the analysis showed no significant relation when CSE was high. 
A potential shortcoming is that Study 1 relied on a single source: Work load, emotional job demands, CSE and depression were all assessed with self-report questionnaires, and thus introducing mono-method bias. CSE and depression are constructs that refer to a person's subjective perceptions and experiences and they are adequately assessed with self-report questionnaires. This may not be necessarily true for workload and emotional job demands, which can also be operationalized in a more objective way. The aim of Study 2 was therefore to test the hypothesized relationships between CSE, job demands and distress by using an objective operationalization of job demands. We therefore compared regular day work to shift work as a specific job demand in Study 2 .

\section{STUDY 2: CSE MODERATES THE RELATIONSHIP BETWEEN SHIFT WORK AND IRRITATION}

\section{Method}

\section{Participants}

This sample consisted of 172 employees (44\% response rate) in a German hospital, of which $66 \%$ were female. The average age was 39.9 years $(S D=11.6)$, ranging from 18 to 68 years. The participants were occupied in all units of the hospital, $52.3 \%(N=90)$ as nurses, $27.9 \%(N=48)$ as doctors, and $19.8 \%(N=34)$ in nonmedical functions, such as cleaner, engineer, or office worker. All were full-time employed, with an average of 39.1 working hours $(S D=12.4)$ per week, and worked on average 16.4 years $(S D=11.9$ year $)$ in the organization. In total, 94 (55\%) were involved in shift work and $78(45 \%)$ had regular work hours.

\section{Measures}

CSE. The German translation of the core self-evaluations scale was applied (Stumpp, Muck, Hülsheger, Judge, \& Maier, 2010). Internal consistency (Cronbach's $\alpha$ ) of the scale amounted to .86 in the present study.

Shift work. Shift work was determined by asking participants whether they were involved in irregular work, where regular was defined as work between 07:30/ 8:00 a.m. and 17:00/18:00 p.m., and unchanging across the days (Costa, 2003). The binary variable shift work was coded as $1=$ shift work, $0=$ no shift work. Of the 94 shift workers, 90 were involved in day shifts (alternating early, middle, and late shifts), and the remaining four alternated day shifts with night shifts.

Irritation. The instrument comprises eight items that are specifically tailored to work situations (Mohr et al., 2006). The construct irritation is composed of two interrelated aspects. Three items pertain to the aspect rumination, which refers to the cognitive aspect of irritation and queries whether an individual has trouble in cognitively detaching from a day's work. It includes items such as "At home I still think about problems at work". The five remaining items measure the aspect irritability, which relates to the emotional component of irritation, such as "I am easily agitated" and "Without wanting it, I often react moodily to others". Items are queried via a 7-point scale ranging from $1=$ "never" to 7 = "almost always". In the present study, Cronbach's $\alpha$ of irritation amounted to .84 .

Control variable. As in Study 1, gender was added as a control variable. Potential gender differences pertain to the vulnerability to job demands and depressive symptoms (Herrero et al., 2012; Smith \& Bielecky, 2012).

\section{Results}

Table 3 provides descriptive statistics and intercorrelations of the variables in Study 2. The results revealed a negative correlation between CSE and irritation. The zero-order correlation between shift work and irritation was not statistically significant. The statistical confirmation of Hypothesis 2 is provided in Table 4 and further illustrated in Figure 3. Regression analysis showed that CSE moderated the relationship between day shift work and irritation. Above and beyond a main effect of CSE on irritation, CSE functioned as a moderator of the relationship between shift work and irritation, such that the relationship was stronger and positive when CSE was

TABLE 3

Reliabilities, means, and standard deviations of, and bivariate correlations between, variables of Study 2

\begin{tabular}{lccccc}
\hline & Cronbach's $\alpha$ & Mean (SD) & 1 & 2 & 3 \\
\hline 1. Gender & - & - &. & & \\
2. Irritation & .84 & $2.95(1.10)$ & .03 &. & \\
3. CSE & .86 & $3.83(0.55)$ & -.06 & $-.54 * * *$ &. \\
4. Shift work & - & - & .11 & .13 & -.09 \\
\hline
\end{tabular}

$* * * p<.001$.

TABLE 4

Irritation as a function of CSE and shift work, with gender as control variable (Study 2)

\begin{tabular}{lcc}
\hline \multicolumn{2}{c}{ Irritation } & \\
\hline Variable & $B$ & $S D$ \\
\hline Intercept & $2.841^{* * *}$ & 0.112 \\
Gender & -0.044 & 0.158 \\
Shift work & 0.225 & 0.153 \\
CSE & $-0.799 * * *$ & 0.174 \\
Shift work $\times$ CSE & $-0.683 *$ & 0.277 \\
$R^{2}$ & .33 & \\
\hline$* * * p<.001, * p<.05$. & &
\end{tabular}




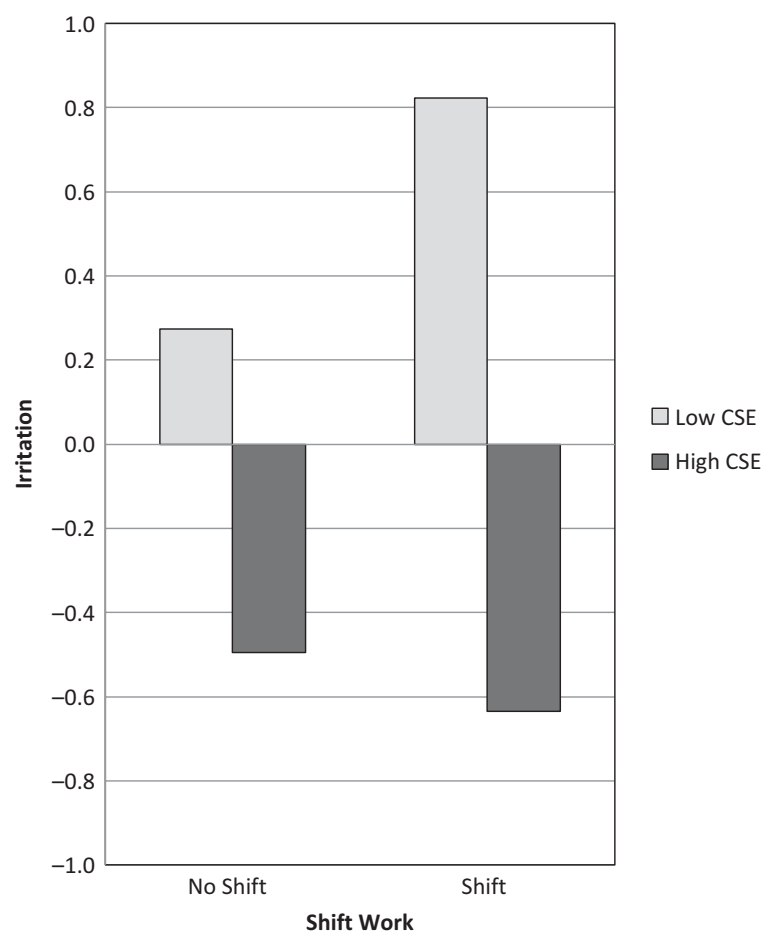

Figure 3. Study 2: Irritation as a function of day shift work and core self-evaluations (CSE).

low and slightly negative when CSE was high. A simple slope analysis revealed a significant slope for low CSE, $\beta=.55, t(150)=2.83, p<.01$. In contrast, the slope for high CSE was not significant $(p>.4)$.

\section{Brief discussion of Study 2}

Apart from revealing a strong negative main relationship between CSE and irritation, results of Study 2 confirmed Hypothesis 2, indicating that CSE buffers the negative influence of shift work on irritation. As Figure 3 illustrates, individuals high in CSE reported comparatively low irritation values, irrelevant of whether they were involved in shift work or not. In contrast, to be involved in shift work or not mattered strongly to those employees low in CSE: Employees who lacked this important person-related resource and were involved in shift work experienced significantly more irritation than those who were not involved in shift work.

\section{GENERAL DISCUSSION}

The present article adds to existing notions on how negative strain reactions may be explained by the interplay between job demands and resources. Contemporary research on the relationship between job demands and strain have demonstrated the potential role of job-related resources (Demerouti et al., 2001; Schaufeli \& Bakker, 2004). We argued that contemporary theory should place more emphasis on the influence of person-related resources originating from long-lasting personality traits as a potential buffer against the negative effects of job demands. Two studies therefore tested whether individuals' evaluation of self-worth, functioning, and control, approached by core self-evaluations (CSE), may function as a person-related resource and as such act as a buffer against the effects of job demands on psychological distress.

Findings from both studies fully supported the idea that CSE moderates the relationship between job demands and psychological distress with data from different organizations, involving both subjective measures (Study 1) as well as an objective measure (Study 2) of job demands and using different operationalizations of psychological distress (depression in Study 1 and irritation in Study 2). Both studies yielded a highly similar pattern of results, namely considerable strain reactions to high job demands in individuals scoring low on CSE, and the typical absence of these strain reactions to high job demands in individuals scoring high on CSE. These results seem to indicate that CSE functions as a personrelated resource and, as such, acts as a buffer against the potential negative effects of job demands on psychological well-being. Similar to the present study, researchers have previously hypothesized that CSE moderates the relationship between job stressors and strain, but failed to find empirical support for their hypothesis (Kammeyer-Mueller et al., 2009).

The present results add to the literature on CSE that has emphasized that the construct positively relates to well-being and job satisfaction (Judge, Bono, Erez, \& Locke, 2005; Judge \& Hurst, 2007; van Doorn, Lang, \& Weijters, 2010). CSE captures four well-established personality traits that have each shown individual susceptibility to strain reactions. Results show that CSE apparently functions as an active psychological buffer against the effects that job demands have on strain reactions. The present outcomes add to recent literature in demonstrating that successful person-related resources may originate from an individual's long-lasting personality structure of an inherent positive self-evaluation of self-worth, control and functioning.

Recent ideas view CSE as more than the sum of its four constituents, and as a basis from which individuals view and act upon stressful stimuli (Chang et al., 2012; Ferris et al., 2012; Kammeyer-Mueller et al., 2009; van Doorn et al., 2010). Our findings suggest that the higher order construct of CSE may indeed be more than the sum of the four subtraits: Overall, the pattern of our results is in line with meta-analytic findings revealing a negative relationship between the four CSE subtraits and strain perceived by employees (Kammeyer-Mueller et al., 2009). Interestingly, however, zero-order correlations of CSE with depression, $r=-.39, p<.01$, and with irritation, $r=-.54, p<.01$, found in our studies exceeded the average uncorrected correlation $(r=-.24)$ reported by 
Kammeyer-Mueller and colleagues (2009). A potential explanation may be that CSE was conceptualized by averaging findings for the four subtraits in the metaanalysis, whereas we used the core self-evaluations scale measuring a single higher order factor at the intersection of self-esteem, locus of control, generalized selfefficacy, and emotional stability (Chang et al., 2012).

As mentioned in the introduction, the construct CSE should be considered as different from recently introduced job-related personal resources (Xanthopoulou et al., 2007, 2009). These recently studied personal resources included general self-efficacy, optimism, and organizational based self-esteem (Xanthopoulou et al., 2007) and were found to act as successful buffers between job demands and negative strain reactions. These resources are, however, believed to be transient and more domain specific as they are conceptually closely related to job-related resources (Xanthopoulou et al., 2007, 2009). They therefore fit well in the Job-Demands Resource model where resources are to be found within a work context. These personal resources are therefore conceptually different from CSE that acts as a broad scope and domain unspecific (Chang et al., 2012), person-related resource (Hobfoll, 2002, 2011; Xanthopoulou et al., 2007, 2009). Future research should reveal whether CSE is at the basis of why job-related resources have been successful in buffering between demands and strain reactions. It is possible that CSE, as a person-related resource, is linked to a more effective development over time of cognitive features and action patterns that may be beneficial in a work context (Hobfoll, 1989).

The potential benefit of person-related resources to bolster against ill-effects of job demands has been based on the notion of conservation of resources. It is assumed that individuals differ in how they actively seek to increase their resources, but may also diverge in attempting to minimize resource loss (Hobfoll, 1989, 2011). Indeed, high CSE individuals may be more efficient in mobilizing and recruiting external job resources, or in developing effective control and management of existing external resources. This agrees with the recent suggestion that high CSE individuals may actively seek out not only more challenging but also more resourceful work situations (Judge \& Hurst, 2007; van Doorn \& Lang, 2010; van Doorn et al., 2010). Future research is needed to establish whether the found moderation is due to mobilizing new resources or to minimizing resource loss.

The present findings add to existing theories that describe the potential benefit of job-related resources as context independent, and are thus applicable across a variety of organizations and job demands (Bakker et al., 2007, 2010). Indeed, the present results reveal a similar data pattern in two studies, portraying two different organizations, and focusing on three separate types of job demand measurements with potential impacts on two types of psychological distress. These consistent outcomes indicate that CSE moderates the relationship between job demands and psychological distress and as such functions as a person-related resource and establishes a buffer between a variety of job demands and several forms of psychological distress.

\section{Limitations and future study}

Potential limitations of the present investigations include that the studied workload and emotional demand measures of the first study were based on self-report and reflected employees' perceptions on job demands. Furthermore the emotional job demands scale showed a relatively low internal consistency. The results may therefore be biased even though the second study shows a similar data pattern when job demands are measured more objectively.

There is an apparent negative overlap $(r=-.36)$ between the constructs depression and CSE. CSE captures positive emotional and internal control and selfworth, whereas depression reflects negative emotion, low self-worth, and loss of energy. However, such a potential overlap does not explain why a similar data pattern including the moderation only pertains to high CSE. Moreover, it does not explain why a similar moderation was found again via the alternative measurement of demand (Wall, Jackson, Mullarkey, \& Parker, 1996), namely via day shift work, and when strain reactions were captured by the construct irritation (Mohr et al., 2006).

Final limitations include the cross-sectional nature of the two studies and the relatively low job demands. In Study 1, job demands were based on self-report, and job demand in Study 2 pertained predominantly to day shift work. Improvements would include a longitudinal or experimental design in which manipulations of job demand, ranging between low and high, will lead to several levels of strain reactions or performance decrement. The question is then whether CSE will remain a strong buffer against the effects of several levels of manipulated demand on strain reactions and performance.

In sum, the present article adds to and combines existing literature by emphasizing that core self-evaluations (CSE), as an established factor in job satisfaction and employee well-being (Judge et al., 2003; Judge \& Hurst, 2007), may provide a person-related and domain unspecific resource that acts as a buffer between job demands and potential negative strain reactions. These findings may have practical and managerial implications. First they show that organizations need to avoid high job demands, as they can be strong predictors of psychological distress and thus threaten a sustainable work-force. To that end, employees' person-related resources may 
guide selection procedures, but may also provide a basis for interventions that are aimed at the special care of employees with less person-related resilience to high job demand, in order to prevent negative strain-reactions and to promote work motivation. Further research is required to add to existing theory by investigating how CSE, as a domain unspecific person-related resource is potentially related to the established success of job resources in providing an effective buffer between the effect of job demands on strain reactions (Chang et al., 2012; Demerouti et al., 2001; Ferris et al., 2012; Van Veldhoven et al., 2002).

\section{REFERENCES}

American Psychiatric Association. (2000). Diagnostic and statistical manual of mental disorders (4th ed.). Washington, DC: Author.

Bakker, A. B., \& Demerouti, E. (2007). The job demands-resources model: State of the art. Journal of Managerial Psychology, 22, 309-328. doi:10.1108/02683940710733115

Bakker, A. B., Demerouti, E., \& Euwema, M. C. (2005). Job resources buffer the impact of job demands on burnout. Journal of Occupational Health Psychology, 10, 170-180. doi:10.1037/10768998.10.2.170

Bakker, A. B., Demerouti, E., \& Verbeke, W. (2004). Using the job demands-resources model to predict burnout and performance. Human Resource Management, 43, 83-104. doi:10.1002/ hrm.20004

Bakker, A. B., Hakanen, J. J., Demerouti, E., \& Xanthopoulou, D. (2007). Job resources boost work engagement, particularly when job demands are high. Journal of Educational Psychology, 99, 274-284. doi:10.1037/0022-0663.99.2.274

Bakker, A. B., van Veldhoven, M., \& Xanthopoulou, D. (2010). Beyond the demand-control model: Thriving on high job demands and resources. Journal of Personnel Psychology, 9, 3-16. doi:10.1027/1866-5888/a000006

Bandura, A. (1994). Regulative function of perceived self-efficacy. In M. G. Rumsey, C. B. Walker \& J. H. Harris (Eds.), Personnel selection and classification (pp. 261-271). Hillsdale, $\mathrm{NJ}$ : Lawrence Erlbaum Associates.

Best, R. G., Stapleton, L. M., \& Downey, R. G. (2005). Core selfevaluations and job burnout: The test of alternative models. Journal of Occupational Health Psychology, 10, 441-451. doi:10.1037/ 1076-8998.10.4.441

Bolger, N., \& Schilling, E. A. (1991). Personality and the problems of everyday life: The role of neuroticism in exposure and reactivity to daily stressors. Journal of Personality, 59, 355-386. doi:10.1111/ j.1467-6494.1991.tb00253.x

Bolger, N., \& Zuckerman, A. (1995). A framework for studying personality in the stress process. Journal of Personality and Social Psychology, 69, 890-902. doi:10.1037/0022-3514.69.5.890

Chang, C.-H., Ferris, D. L., Johnson, R. E., Rosen, C. C., \& Tan, J. A. (2012). Core self-evaluations: A review and evaluation of the literature. Journal of Management, 38, 81-128. doi:10.1177/ 0149206311419661

Cohen, S., \& Edwards, J. R. (1989). Personality characteristics as moderators of the relationship between stress and disorder. In R. W. J. Neufeld (Ed.), Advances in the investigation of psychological stress (pp. 235-283). Oxford: John Wiley \& Sons.

Costa, G. (2003). Shift work and occupational medicine. Occupational Medicine, 53, 83-88. doi:10.1093/occmed/kqg045

Crawford, E. R., LePine, J. A., \& Rich, B. L. (2010). Linking job demands and resources to employee engagement and burnout: A theoretical extension and meta-analytic test. Journal of Applied Psychology, 95, 834-848. doi:10.1037/a0019364 de Jonge, J., \& Dormann, C. (2006). Stressors, resources, and strain at work: A longitudinal test of the triple-match principle. Journal of Applied Psychology, 91, 1359-1374. doi:10.1037/00219010.91.5.1359

de Jonge, J., Dormann, C., van Vegchel, N. (2004). Taakeisen, hulpbronnen en psychische gezondheid: Het Demand-Induced Strain Compensation (DISC)-Model. Gedrag en Organisatie, 17, 59-79.

de Jonge, J., Spoor, E., Sonnentag, S., Dormann, C., \& van den Tooren, M. (2012). "Take a break?!" off-job recovery, job demands, and job resources as predictors of health, active learning, and creativity. European Journal of Work and Organizational Psychology, 21, 321-348. doi:10.1080/1359432X.2011.576009

de Pater, I. E., Schinkel, S., \& Nijstad, B. A. (2007). Validatie van de Nederlandstalige core self-evaluations vragenlijst [Validation of the Dutch core self-evaluations scale]. Gedrag En Organisatie, 20, $82-100$.

Demerouti, E., Bakker, A. B., Nachreiner, F., \& Ebbinghaus, M. (2002). From mental strain to burnout. European Journal of Work and Organizational Psychology, 11, 423-441. doi:10.1080/ 13594320244000274

Demerouti, E., Bakker, A. B., Nachreiner, F., \& Schaufeli, W. B. (2001). The job demands-resources model of burnout. Journal of Applied Psychology, 86, 499-512. doi:10.1037//00219010.86.3.499

Demerouti, E., Geurts, S. A. E., Bakker, A. B., \& Euwema, M. (2004). The impact of shiftwork on work-home conflict, job attitudes and health. Ergonomics, 47, 987-1002. doi:10.1080/00140130410001670408

Demerouti, E., Mostert, K., \& Bakker, A. B. (2010). Burnout and work engagement: A thorough investigation of the independency of both constructs. Journal of Occupational Health Psychology, 15, 209-222. doi:10.1037/a0019408

Dormann, C., \& Zapf, D. (2002). Social stressors at work, irritation, and depressive symptoms: Accounting for unmeasured third variables in a multi-wave study. Journal of Occupational and Organizational Psychology, 75, 33-58. doi:10.1348/ 096317902167630

Dowrick, C., Kokanovic, R., Hegarty, K., Griffiths, F., \& Gunn, J. (2008). Resilience and depression: Perspectives from primary care. Health: An Interdisciplinary Journal for the Social Study of Health, Illness and Medicine, 12, 439-452. doi:10.1177/ 1363459308094419

Drake, C. L., Roehrs, T., Richardson, G., Walsh, J. K., \& Roth, T. (2004). Shift work sleep disorder: Prevalence and consequences beyond that of symptomatic day workers. Sleep, 27, 1453-1462.

Ferris, D. L., Johnson, R. E., Rosen, C. C., Djurdjevic, E., Chang, C. -H., \& Tan, J. A. (2012). When is success not satisfying? Integrating regulatory focus and approach/avoidance motivation theories to explain the relation between core self-evaluation and job satisfaction. Journal of Applied Psychology, 98, 342-353. doi:10.1037/a0029776

Folkman, S. (1984). Personal control and stress and coping processes: A theoretical analysis. Journal of Personality and Social Psychology, 46, 839-852. doi:10.1037/h0029442

Frankenhaeuser, M., \& Johansson, G. (1986). Stress at work: Psychobiological and psychosocial aspects. International Review of Applied Psychology, 35, 287-299. doi:10.1111/j.14640597.1986.tb00928.x

Frost, P. J., \& Jamal, M. (1979). Shift work, attitudes, and reported behavior: Some associations between individual characteristics and hours of work and leisure. Journal of Applied Psychology, 64, 66-71. doi:10.1037/0021-9010.64.1.66

Gabriel, A. S., Diefendorff, J. M., \& Erickson, R. J. (2011). The relations of daily task accomplishment satisfaction with changes in affect: A multilevel study in nurses. Journal of Applied Psychology, 96, 1095-1104. doi:10.1037/a0023937

Gallagher, V. C. (2012). Managing resources and need for cognition: Impact on depressed mood at work. Personality and Individual Differences, 53, 534-537. doi:10.1016/j.paid.2012.04.025 
Ganster, D. C., \& Fusilier, M. R. (1989). Control in the workplace. In C. L. Cooper \& I. T. Robertson (Eds.), International review of industrial and organizational psychology 1989 (pp. 235-280). Oxford: John Wiley \& Sons.

Ganster, D. C., \& Schaubroeck, J. (1991). Work stress and employee health. Journal of Management, 17, 235-271. doi:10.1177/ 014920639101700202

Härmä, M. I., Ilmarinen, J., Knauth, P., \& Rutenfranz, J. (1988). Physical training intervention in female shift workers: I. The effects of intervention of fitness, fatigue, sleep, and psychosomatic symptoms. Ergonomics, 31, 39-50. doi:10.1080/00140138808966647

Heckhausen, J., \& Schulz, R. (1995). A life-span theory of control. Psychological Review, 102, 284-304. doi:0033-295X/95/S3.00

Herrero, S. G., Saldaña, M. Á. M., Rodriguez, J. G., \& Ritzel, D. O. (2012). Influence of task demands on occupational stress: Gender differences. Journal of Safety Research, 43, 365-374. doi:10.1016/ j.jsr.2012.10.005

Hobfoll, S. E. (1989). Conservation of resources: A new attempt at conceptualizing stress. American Psychologist, 44, 513-524. doi: 10.1037/0003-066X.44.3.513

Hobfoll, S. E. (2002). Social and psychological resources and adaptation. Review of General Psychology, 6, 307-324. doi:10.1037// 1089-2680.6.4.307

Hobfoll, S. E. (2011). Conservation of resource caravans and engaged settings. Journal of Occupational and Organizational Psychology, 84, 116-122. doi:10.1111/j.2044-8325.2010.02016.x

Hockey, G. R. J. (1997). Compensatory control in the regulation of human performance under stress and high workload: A cognitiveenergetical framework. Biological Psychology, 45, 73-93. doi: 10.1016/S0301-0511(96)05223-4

Jex, S. M., \& Bliese, P. D. (1999). Efficacy beliefs as a moderator of the impact of work-related stressors: A multilevel study. Journal of Applied Psychology, 84, 349-361. doi:10.1037/00219010.84.3.349

Jex, S. M., Bliese, P. D., Buzzell, S., \& Primeau, J. (2001). The impact of self-efficacy on stressor-strain relations: Coping style as an explanatory mechanism. Journal of Applied Psychology, 86, 401-409. doi:10.1037/0021-9010.86.3.401

Jex, S. M., \& Elacqua, T. C. (1999). Self-esteem as a moderator: A comparison of global and organization-based measures. Journal of Occupational and Organizational Psychology, 72, 71-81. doi:10.1348/096317999166509

Judge, T. A., \& Bono, J. E. (2001). Relationship of core self-evaluations traits-self-esteem, generalized self-efficacy, locus of control, and emotional stability-with job satisfaction and job performance: A meta-analysis. Journal of Applied Psychology, 86, 80-92. doi:10.1037//0021-9010.86.1.80

Judge, T. A., Bono, J. E., Erez, A., \& Locke, E. A. (2005). Core self-evaluations and job and life satisfaction: The role of selfconcordance and goal attainment. Journal of Applied Psychology, 90, 257-268. doi:10.1037/0021-9010.90.2.257

Judge, T. A., Erez, A., Bono, J. E., \& Thoresen, C. J. (2002). Are measures of self-esteem, neuroticism, locus of control, and generalized self-efficacy indicators of a common core construct?. Journal of Personality and Social Psychology, 83, 693-710. doi:10.1037// 0022-3514.83.3.693

Judge, T. A., Erez, A., Bono, J. E., \& Thoresen, C. J. (2003). The core selfevaluations scale: Development of a measure. Personnel Psychology, 56, 303-331. doi:10.1111/j.1744-6570.2003.tb00152.x

Judge, T. A., \& Hurst, C. (2007). Capitalizing on one's advantages: Role of core self-evaluations. Journal of Applied Psychology, 92, 1212-1227. doi:10.1037/0021-9010.92.5.1212

Judge, T. A., Locke, E. A., \& Durham, C. C. (1997). The dispositional causes of job satisfaction. Research in Organisational Behavior, 19, 151-188. doi:10.1111/j.1464-0597.2007.00318.x

Judge, T. A., Locke, E. A., Durham, C. C., \& Kluger, A. N. (1998). Dispositional effects on job and life satisfaction: The role of core evaluations. Journal of Applied Psychology, 83, 17-34.
Kahneman, D. (1973). Attention and effort. Englewood Cliffs, NJ: Prentice Hall.

Kammeyer-Mueller, J. D., Judge, T. A., \& Scott, B. A. (2009). The role of core self-evaluations in the coping process. Journal of Applied Psychology, 94, 177-195. doi:10.1037/a0013214

Kandolin, I. (1993). Burnout of female and male nurses in shiftwork. Ergonomics, 36, 141-147. doi:10.1080/ 00140139308967865

Kanfer, R., \& Ackerman, P. L. (1989). Motivation and cognitive abilities: An integrative/aptitude-treatment interaction approach to skill acquisition. Journal of Applied Psychology, 74, 657-690. doi:10.1037/0021-9010.74.4.657

Karasek, R., Brisson, C., Kawakami, N., Houtman, I., Bongers, P., \& Amick, B. (1998). The Job Content Questionnaire (JCQ): An instrument for internationally comparative assessments of psychosocial job characteristics. Journal of Occupational Health Psychology, 3, 322-355. doi:10.1037//1076-8998.3.4.322

Kobasa, S. C. (1979). Stressful life events, personality, and health: An inquiry into hardiness. Journal of Personality and Social Psychology, 37, 1-11. doi:10.1037/0022-3514.37.1.1

Kobasa, S. C., Maddi, S. R., \& Zola, M. A. (1983). Type A and hardiness. Journal of Behavioral Medicine, 6, 41-51. doi: $10.1007 / \mathrm{bf} 00845275$

Kobasa, S. C., \& Puccetti, M. C. (1983). Personality and social resources in stress resistance. Journal of Personality and Social Psychology, 45, 839-850. doi:10.1037/0022-3514.45.4.839

Kroenke, K., \& Spitzer, R. L. (2002). The PHQ-9: A new depression diagnostic and severity measure. Psychiatric Annals, 32, 509-515.

Luria, G. I. L., \& Torjman, A. (2009). Resources and coping with stressful events. Journal of Organizational Behavior, 30, 685-707. doi: $10.1002 /$ job.551

Mark, G., \& Smith, A. P. (2012). Occupational stress, job characteristics, coping, and the mental health of nurses. British Journal of Health Psychology, 17, 505-521. doi:10.1111/j.20448287.2011.02051.x

May, D. R., Schwoerer, C. E., Reed, K., \& Potter, P. (1997). Employee reactions to ergonomic job design: The moderating effects of health locus of control and self-efficacy. Journal of Occupational Health Psychology, 2, 11-24. doi:10.1037/1076-8998.2.1.11

Mohr, G., Müller, A., Rigotti, T., Aycan, Z., \& Tschan, F. (2006). The assessment of psychological strain in work contexts: Concerning the structural equivalency of nine language adaptations of the irritation scale. European Journal of Psychological Assessment, 22, 198-206. doi:10.1027/1015-5759.22.3.198

Mohr, G., Rigotti, T., \& Müller, A. (2005). Irritation-Ein Instrument zur Erfassung psychischer Beanspruchung im Arbeitskontext. Skalen- und Itemparameter aus 15 Studien. Zeitschrift Für Arbeits- Und Organisationspsychologie, 49, 44-48. doi:10.1026/ 0932-4089.49.1.44

Mohr, G., \& Wolfram, H.-J. (2010). Stress among managers: The importance of dynamic tasks, predictability, and social support in unpredictable times. Journal of Occupational Health Psychology, 15, 167-179. doi:10.1037/a0018892

Moyle, P. (1995). The role of negative affectivity in the stress process: Tests of alternative models. Journal of Organizational Behavior, 16, 647-668. doi:10.1002/job.4030160705

Parkes, K. R. (1990). Coping, negative affectivity, and the work environment: Additive and interactive predictors of mental health. Journal of Applied Psychology, 75, 399-409. doi:10.1037/00219010.75.4.399

Parkes, K. R. (1991). Locus of control as moderator: An explanation for additive versus interactive findings in the demand-discretion model of work stress? British Journal of Psychology, 82, 291312. doi:10.1111/j.2044-8295.1991.tb02401.x

Pierce, J. L., Gardner, D. G., Dunham, R. B., \& Cummings, L. L. (1993). Moderation by organization-based self-esteem of role condition-employee response relationships. Academy of Management Journal, 36, 271-288. doi:10.2307/256523 
Schaufeli, W. B., \& Bakker, A. B. (2004). Job demands, job resources, and their relationship with burnout and engagement: A multi-sample study. Journal of Organizational Behavior, 25, 293315. doi:10.1002/job. 248

Schneider, T. R., Rench, T. A., Lyons, J. B., \& Riffle, R. R. (2012). The influence of neuroticism, extraversion and openness on stress responses. Stress and Health. Journal of the International Society for the Investigation of Stress, 28, 102-110. doi:10.1002/smi.1409

Semmer, N. K., Jacobshagen, N., Meier, L. L., \& Elfering, A. (2007). Occupational stress research: The "Stress-as-Offense-to-Self" perspective. In S. McIntyre \& J. Houdmont (Eds.), Occupational health psychology: European perspectives on research, education and practice (Vol. 2, pp. 43-60). Castelo da Maia: ISMAI.

Smillie, L. D., Yeo, G. B., Furnham, A. F., \& Jackson, C. J. (2006). Benefits of all work and no play: The relationship between neuroticism and performance as a function of resource allocation. Journal of Applied Psychology, 91, 139-155. doi:10.1037/00219010.91.1.139

Smith, P. M., \& Bielecky, A. (2012). The impact of changes in job strain and its components on the risk of depression. American Journal of Public Health, 102, 352-358. doi:10.2105/ ajph.2011.300376

Spector, P. E., Cooper, C. L., Sanchez, J. I., O‘Driscoll, M., Sparks, K., Bernin, P., \& Yu, S. (2002). Locus of control and well-being at work: How generalizable are Western findings?. Academy of Management Journal, 45, 453-466. doi:10.2307/3069359

Stumpp, T., Muck, P. M., Hülsheger, U. R., Judge, T. A., \& Maier, G. W. (2010). Core self-evaluations in Germany: Validation of a German measure and its relationships with career success. Applied Psychology: An International Review, 59, 674-700. doi: 10.1111/ j.1464-0597.2010.00422.x

van Doorn, R. R. A., \& Lang, J. W. B. (2010). Performance differences explained by the neuroticism facets withdrawal and volatility, variations in task demand, and effort allocation. Journal of Research in Personality, 44, 446-452. doi:10.1016/j.jrp.2010.05.004 van Doorn, R. R. A., Lang, J. W. B., \& Weijters, T. (2010). Self-reported cognitive failures: A core self-evaluation? Personality and Individual Differences, 49, 717-722. doi:10.1016/ j.paid.2010.06.013

Van Veldhoven, M., De Jonge, J., Broersen, S., Kompier, M., \& Meijman, T. (2002). Specific relationships between psychosocial job conditions and job-related stress: A three-level analytic approach. Work \& Stress, 16, 207-228. doi:10.1080/ 02678370210166399

Wall, T. D., Jackson, P. J., Mullarkey, S., \& Parker, S. K. (1996). The demands-control model of job strain: A more specific test. Journal of Occupational and Organizational Psychology, 69, 153-166. doi:10.1111/j.2044-8325.1996.tb00607.x

Warr, P. (1990). The measurement of well-being and other aspects of mental health. Journal of Occupational Psychology, 63, 193-210. doi:10.1111/j.2044-8325.1990.tb00521.x

Xanthopoulou, D., Bakker, A. B., Demerouti, E., \& Schaufeli, W. B. (2007). The role of personal resources in the job demands-resources model. International Journal of Stress Management, 14, 121-141. doi:10.1037/1072-5245.14.2.121

Xanthopoulou, D., Bakker, A. B., Demerouti, E., \& Schaufeli, W. B. (2009). Reciprocal relationships between job resources, personal resources, and work engagement. Journal of Vocational Behavior, 74, 235-244. doi:10.1016/j. jvb.2008.11.003

Xanthopoulou, D., Bakker, A. B., Demerouti, E., \& Schaufeli, W. B. (2012). A diary study on the happy worker: How job resources relate to positive emotions and personal resources. European Journal of Work and Organizational Psychology, 21, 489-517. doi:10.1080/1359432X.2011.584386

Original manuscript received October 2012 Revised manuscript received September 2013 Revised manuscript accepted October 2013 First published online November 2013 